\title{
DOCTOR ALBERT COOK AND THE EARLY DAYS OF THE CHURCH MISSIONARY SOCIETY'S MEDICAL MISSION TO UGANDA
}

by

\author{
W. D. FOSTER
}

ON 1 October 1896, there disembarked at Mombasa a party of twelve Church Missionary Society missionaries bound for Uganda. One of the nine men was Dr. A. R. Cook and one of the three women a Miss K. Timpson, a qualified nurse who had trained at Guy's Hospital.

They planned to march to Uganda via the northern route, through British territory, and their caravan leader was the veteran Dr. Baxter of Mpawpa. Cook noted that Baxter was 'as skilful with his rifle as he was patient with the men, quite unmoved by misfortune and resourceful in difficulties, he was admirable at his job'. Two months were spent in getting the caravan together, for a party of a dozen Europeans with their baggage required no less than 500 porters. This number they were quite unable to recruit and had eventually to make do with but 200 supplemented by fifty-four donkeys which Baxter had clothed in suits of 'amerikani', hoping to protect them against tsetse flies. Even so, much of the missionaries' baggage had to be sent round via the southern route and took two years to reach Uganda. The caravan started its journey on 28 November but by the time they had reached Rabai, just at the end of Mombasa creek, desertion and sickness had reduced their porters to 174 and further loads had to be left behind to come up the southern route.

On 1 December they moved on towards Kibwezi, which was reached by a cart track through the thick bush of the Taru desert. They reached Kibwezi by 19 December and were hospitably entertained at the missionary station. Pushing on, the caravan was much hampered by sickness among the porters which Cook attributed to their unsuitable food. This consisted of hard Indian corn which required six hours' boiling to soften it, time which, at the end of a tiring day, could never be spared for the purpose. Moreover, the three women missionaries all became ill and had to be carried.

Nonetheless, Christmas was duly celebrated with a dinner of curried antelope'shot two days ago' and a four-month-old plum-pudding. Appropriately enough, they even 'saw plenty of snow, for Kilimanjaro, with its mighty peaks, Kibo and Mwenzi, was in full view (over 80 miles to the south) for most of the march'.

On 27 December, Cook, Baxter and Miss Timpson formed a surgical team and performed an unspecified operation on an American missionary at Kilunga, for a 'curable disease which was wearing him out and making his life a burden'. Indeed a considerable amount of medical work was done on the journey for Cook attended to a total of 2,230 patients en route, as well as members of the caravan. They were compelled to abandon, at various stations, 'some twelve porters who were unfit to travel through dysentery, pneumonia, ulcers, fever and other causes', but, so far as 


\section{W. D. Foster}

they knew, only one of these porters died, of pneumonia. They reached Machakos on 31 December and descended the spectacular escarpment of the Rift Valley on 17 January. On 19 January, as the caravan wound its way along the floor of the Rift Valley, Cook and Weatherhead were unable to resist the temptation to climb to the rim of the crater of the extinct volcano, Mount Longonot, which lay in their path. The party reached Mumias on 6 February and there split up, nine missionaries going by steam launch across the lake to Munyongo, 'nearest port to Mengo, the capital of Uganda' which they reached on 15 February. The other three, Cook, Weatherhead and Baskerville marched round by land and reached Mengo on 19 February. The cost, per person, of the journey from the coast, walking as they did, was about $£ 100$. At that time the appproximate cost of transporting $45 \mathrm{lbs}$. of goods from Mombasa to Uganda was $£ 7$ so that medical supplies, for example Epsom salts, which cost $2 d$. per lb. in England, cost $3 s$. $2 d$. in Uganda.

Cook began his medical work at Mengo on 22 February 1897, seeing out-patients in a little shed which one of the missionaries, a Miss Pilgrim, was already using as a dispensary, and was soon seeing between fifty and eighty patients a day, besides operations, which were performed publicly, on a camp bed. The administration of chloroform, the painless operation and the recovery from the anaesthetic, were to the natives quite miraculous. The effect of intramuscular quinine on a comatose case of cerebral malaria or of digitalis in congestive cardiac failure was hardly less magical, so that it is not surprising that a patient, blind from corneal scars who was cured by cutting a window in his iris, should say that Cook must be God.

On his arrival at Mengo, Albert Cook lost no time in beginning his medical work, the statistics of which date from 22 February 1897 . With a local population estimated to number about 20,000 he rightly judged that there was 'probably good scope for work' and immediately obtained the promise of the Katikiro, or prime minister, that a hospital would be built with wards for male and female patients, an operating room and a store-house. Meanwhile work began at the out-patient dispensary. The first ward, containing six beds, was opened on 15 May, another, also of six beds, was completed on 24 May, and by the end of 1897 a further sixteen-bedded ward had been opened.

During his first year's work, over 17,000 patients were seen at the dispensary and 189 admitted to hospital. 314 minor surgical operations were performed and 140 more serious ones were done under chloroform anaesthesia. The total mortality among the in-patients amounted to only fifteen and, of these, seven died within twenty-four hours of admission. His patients were on the whole well pleased with the attention they received, for only thirteen discharged themselves. The average stay in hospital was long, being 21.5 days.

From the first Cook practised an exceptionally high standard of medicine in his little grass-hut hospital. He kept clinical notes on all patients admitted, preserved them and, eventually, had them bound up and indexed. The notes were written on proper case-sheets with printed heading 'Mengo Hospital' and there were also temperature charts, usually printed, but, when necessary, ruled by hand by the ladies of the mission. It must be admitted that the standard of note-keeping varied and was not infrequently confined to a note on the margin of the temperature chart. But the 


\section{Dr. Albert Cook and the C.M.S. Medical Mission to Uganda}

mere keeping of notes, of any kind, immediately raises the level of medical practice, even though a full physical examination is not recorded for every case and progress notes are meagre. Where Cook was particularly interested in a patient the case notes are models with a full history, family history, past history, complete physical examination and records of laboratory investigations. Cook's early clinical notes show that, when the occasion required, he performed the following range of laboratory tests: haemoglobin estimation, erythrocyte and leucocyte counts, examination of blood for malaria parasites, examination of pus stained for bacteria and similar examination of urethral discharge for gonococci, urine albumen was estimated by Esbach's method, a diabetic patient was weighed regularly and his urine output, specific gravity and glucose content measured, faeces were examined for parasites and sputum stained for tubercle bacilli. In addition, Cook employed the ophthalmoscope and laryngoscope and resorted to clinical photography to record features of interesting patients. Finally, despite the complete lack of proper facilities, whenever possible, Cook performed autopsies on both his native and European patients. Despite his youth and inexperience, with such methods, a real beginning was made to the study of medicine in Uganda and he rapidly established a general knowledge of the disease pattern in the Mengo area.

During his first year's work Cook showed quite definitely the existence in Uganda of rheumatic heart disease, cerebral vascular disease, a variety of benign and malignant tumours, hookworm anaemia, diabetes mellitus, pulmonary and bone tuberculosis, whooping-cough and leukaemia. But, from a practical point of view, 'fever' was his biggest clinical problem for, of all admissions during his first year, fifty-six were thus diagnosed. We have noted that Cook did examine the blood for malaria parasites, at this time, fresh and unstained. There are a number of records of 'Pigmented leucocytes and motile haematozoa in blood', 'Motile parasites in blood and a suspicion of flagellated haematozoa', 'parasites-many flagellated' but a note of the presence or absence of malaria parasites is to be found in but a small minority of his cases of fever. To the inexperienced eye the discovery of malaria parasites in a fresh blood preparation seems to have been difficult, and Cook was doubtless, usually, compelled to resort to the therapeutic test of administering quinine. Quinine appears, almost always, to have rapidly brought the temperature to normal. His surgical work was largely the treatment of injuries, commonly compound fractures and bullet wounds. The Sudanese mutiny in 1897 provided Cook with some experience of military surgery for he saw active service with the Government and Baganda troops. He sent home reports of his activities to the Church Missionary Society headquarters, extracts of which were published, as well as a popular article entitled 'Bullets I have met' from which some details of medical interest may be obtained.

Cook's first experience of treating bullet wounds came in early August 1897, when the Kabaka Mwanga raised a revolt against the Protectorate government. The hospital had to be immediately enlarged with a hut of twelve beds to accommodate the wounded and a considerable variety of bullet wounds was seen. In all, during a few weeks, Cook treated over 150 bullet wounds caused by missiles of all sorts from Snider rifle bullets to lumps of local iron discharged from muzzle-loaders at a range of about fifteen feet. 


\section{W. D. Foster}

Mwanga's revolt had no sooner been put down than, in September, the much more dangerous mutiny of the Sudanese troops took place. The main force of mutineers was at Luba's near the source of the Nile and there, on 19 October, a brisk battle was fought in which one Englishman was killed, another, Jackson, shot through the lung, and the government doctor, Macpherson, wounded in the shoulder. The Acting-Commissioner of Uganda asked for volunteers from the Church Missionary Society missionaries to accompany a Baganda army to Luba's to give moral support, as 'They [the Baganda] placed great confidence in the missionaries'. Cook and Pilkington arrived at Luba's on 23 October and were immediately put to work both medically and militarily.

Cook found it 'interesting watching a skirmish from the top of Luba's Hill and the puffs of smoke looked very picturesque against the dark green of the bananas . . .', and the opportunities for evangelical work were not to be neglected-'Take a single instance: a Mohammedan . . . hit by a bullet in the thigh' who had first had his wound 'poked' by a Mohammedan doctor who caused 'a good deal of pain', was efficiently dealt with by Cook, under general anaesthesia, and when he woke up 'from his painless sleep it was to find his thigh comfortably bandaged and the extracted bullet ready for him to see. During the remaining days of his stay in the hospital he had the advantage of listening with a grateful heart to the simple truths of the Gospel put clearly before him'.

Another engagement on 24 November resulted in forty-two seriously wounded Baganda being sent back to Mengo Hospital. Their wounds had not been dressed for a week and 'the odour was not fragrant'. In one day Cook did seven operations under chloroform and all eight ladies at the mission turned to, under Miss Timpson, to help (they each received a medal from the government later). One of the more interesting patients developed tetanus and Cook, by administering a total of $\mathbf{3 7 0}$ grams of chloral was able to reduce the number of spasms from thirty to four per minute.

The medical work at Mengo speedily increased following Albert Cook's arrival and he most energetically expanded the facilities and improved the standard of investigation and patient care. Mengo Hospital started with Albert Cook as the only doctor and Miss K. Timpson (who married Cook in 1900) the only trained nurse. In 1899 the hospital was reinforced by the arrival of Albert Cook's brother Jack, who, in addition to the London M.B. was also an M.S. and F.R.C.S. In 1901 another trained nurse, the invaluable Miss B. E. Dallison, joined the staff.

The number of beds in the hospital increased steadily from the twenty-eight in use at the end of 1897 to seventy-five in 1901 and the number of in-patients treated per year from 141 to 1,070 during the same period. The increase in out-patients was not so large but in 1901 , over 53,000 patients were seen. The number of surgical operations in 1901 amounted to 368 as compared with 277 in 1897 an increase which had not kept pace with the increase in beds. On the other hand, the gynaecological and obstetrical work had developed enormously. The general mortality rate for all hospital in-patients in 1903 was seven per cent but a number of patients had been moribund on admission. The post-operative mortality rate was four per cent but, as Cook reported, the operations included many of the most serious known to 


\section{Dr. Albert Cook and the C.M.S. Medical Mission to Uganda}

surgery' including laparotomies (by no means a commonplace operation, anywhere, at the end of the nineteenth century), Wheelhouse operations for urethral stricture, and removal of malignant tumours.

The two Cook brothers had, of necessity, both to be 'general' practitioners but an examination of the hospital clinical notes and the letters in the Mengo archives suggests that some division of interests took place. Jack Cook undertook much of the day-to-day administration of the hospital, the correspondence with headquarters, etc., and did most of the surgery. Albert Cook was the physician of the team and his interest in internal medicine is clearly shown by his excellent notes on good cases of valvular heart disease, pneumonia etc. Albert, moreover, seems to have done the bulk of the laboratory investigations and most of the autopsies. Albert was a scholarly student of disease, as can be seen from the collection of books from Mengo Hospital Library (now in the Albert Cook Library at Makerere), for very many of them show his characteristic underlinings, marginal comments and notes of the date when read.

The Mengo Hospital clinical notes are a wonderful source of information on the diseases of Uganda, but their limitations must be understood. In the first place they are not complete since the total of case-notes available for a given year does not correspond to the total of in-patients for the year in the hospital's published statistics. Although some of the notes are very full, others are sketchy in the extreme with no evidence to support the diagnosis given. The dates of admission and discharge are not always noted and some notes are clearly bound up in the wrong volume. It also seems that, as the Cooks became more experienced and busier, their notes became more and more brief. There are also differences which suggest that the notes must be used very cautiously from any statistical point of view; for example, there are no notes of cases of childbirth for the years 1897 and 1898 and, at this time, it is likely that little obstetrics was in fact practised. But, in 1899 , there are notes of thirty-one cases of parturition and yet in $\mathbf{1 9 0 0}$ of only one case. Almost certainly there is some accidental explanation for this. But, bearing these limitations in mind, some observations drawn from the clinical notes from 1897 to 1903 will here be given.

Throughout the period the commonest cause of admission remained 'fever' accounting for a steady twenty per cent of patients and the evidence suggests that most of this was malaria. 'Tick' or relapsing fever was quite commonly diagnosed clinically but the temperature charts rarely show the typical relapsing pattern nor were the spirilla often found in the blood. The diagnosis of tick fever commonly rested on little more than a fever which failed to respond rapidly to quinine therapy. Not more than one or two patients each year were diagnosed as having typhoid fever and a question mark is commonly placed in front of the diagnosis. Syphilis was a common cause of admission in 1903, amounting to about ten per cent of patients. The most common type of this disease seen was tertiary syphilis in various manifestations but some secondary syphilis and congenital syphilis was also seen. Severe septic infections commonly given the diagnosis of 'pyaemia' occurred frequently but the notes of some of these indicate that, today, they would be diagnosed as tropical pyomyositis. Other conditions observed at Mengo during the first six years of the hospital's existence, besides those already mentioned, include elephantiasis, liver abscess, dracunculiasis, 


\section{W. D. Foster}

yaws and rheumatic fever. 'If only', wrote Albert Cook, 'we could squeeze out time to write a few papers'.

It is interesting to examine certain general matters concerned in the organization of Church Missionary Society medical missions such as their methods of finance, administration, recruitment of staff, training of local personnel, the way their efforts spread throughout Uganda, through up-country dispensaries and Toro Hospital, as well as the connection of the medical and evangelical parts of their work.

To take the last point first; it must be remembered that the medical work of the mission was always subordinate to the evangelical side and, indeed, was made, whenever possible, to serve an evangelical purpose. The main reason for having a doctor at the Church Missionary Society headquarters in Uganda was not to work among the sick Africans but to look after any missionary who might fall ill. The attitude of Archdeacon Walker at Mengo, expressed in a letter to Church Missionary Society headquarters in London, was that he did not think the dispensing of medicines did much good in a place where it was 'not needed to draw the people under the influence of the mission'.

The day after A. R. Cook arrived at Mengo, in February 1897, a meeting of missionaries was held and there was a strong body of opinion that Cook himself should undertake evangelical work and that Miss Pilgrim carry on with her small dispensary, calling on Cook for medical advice in emergency only. Miss Timpson, the only other medically-trained missionary, was to be sent to the village of Ngogwe some thirty miles from the capital. Fortunately, largely due to the persuasive powers of Dr. Baxter, 'wiser counsels prevailed'. Cook and Miss Timpson were allowed to begin medical work at Mengo but only on a one-year trial in the first instance.

Cook's own attitude to his duties were that he should preach the Kingdom of God and heal the sick but stressed that the spiritual work was far more important than the relief of physical suffering. When the Cook brothers were officially asked what they regarded as constituting the most urgent claim to the opening of a medical mission, they headed their list with 'Difficulty of otherwise preaching the Gospel' and 'Special evangelistic opportunities especially amongst Indians, Mohammedans and Roman Catholics . . .' and maintained that a doctor 'not of sound evangelical principles would be more bother than he is worth'. One of the disadvantages, to them, of training native African doctors was that the local population might prefer to go to them, in preference to the missionaries, 'because there would be, or might be, no Christian teaching attached to their work'. Certainly, although much play was made of the fact that their hospital was open to all, irrespective of religious creed, attendance at religious instruction was a condition of medical treatment. Cook recorded that 'at first this led to some little demur on the part of the Roman Catholics, who came and protested, but I said they must either have our Gospel-preaching and medicine, or go without the latter. They chose to attend'.

In-patient work was to be preferred to out-patient work because the captive audience was more suitable for spiritual treatment, many of the patients being 'touched by the successful treatment of their diseases'. Indeed the best part of the hospital, evangelistically speaking, was the isolation wards, which were largely filled with patients suffering from syphilis and frequently 'covered with a loathsome 


\section{Dr. Albert Cook and the C.M.S. Medical Mission to Uganda}

eruption, or suffering from foul ulcers'. But, happily, treatment usually proved very satisfactory and a fortnight's vigorous treatment often produced an 'almost miraculous change'. This was a most valuable asset since 'the great majority are very grateful for what is being done for them, and predisposed to listen to our teaching'.

It seems probable that the poor opinion that the kindly and humane government Medical Officer, Robert Moffat, who, though of missionary stock, could see good in Mohammedanism, had of the Church Missionary Society missionaries might well have stemmed from the religious attitudes here indicated; the arrogant attempts to convert, not only heathen, but adherents to perfectly respectable religions, such as Muslims and Roman Catholics, even to the inhuman threat of denial of medical attention to those, who, for reasons of conscience, declined to attend their Protestant service.

With medical work fairly started at their Mengo station, the Church Missionary Society was soon faced with problems concerning its scope and, in particular, its expansion. The value of medical work in the missionary sphere was not seriously questioned by those on the spot but its extent and relation to the evangelical work and its financial implications were matters of lively concern. Between Cook's arrival in 1897 and the middle of 1903 a considerable controversy raged centering partly on the development of the hospital at Mengo and particularly on the proposal to build a second hospital in Toro, a proposition first brought up about September 1898.

Albert Cook and later his brother Jack and Bishop Tucker constituted an 'expansionist' party within the mission whilst Archdeacon Walker formed a focus around which opposition to the overweening pretensions of medicine could concentrate. Over the years Walker wrote many letters to Salisbury Square propounding his views on medical missionary work and a study of these leaves even one prejudiced to the medical side with, at least, respect for his opinions.

A few weeks after Cook's arrival at Mengo, Walker wrote home that he was 'not quite at one with Dr. Cook on the medical work'. He continued, 'I regard the medical work merely from its missionary aspect until it is a native effort. I consider how far it is likely to aid our work not how much suffering will be relieved'. The object of medical work was to reach people who were out of sympathy with the church and to emulate Christ who taught us to take care of the sick. Therefore, although Walker 'could not consider our mission work complete without a hospital or some such institution in which we might show this side of Christian life', for evangelical purposes, clearly, very simple facilities ought to suffice.

Almost at once, Albert Cook drew up plans to build a hospital at a cost of about $£ 300$ - a large sum in relation to the mission's resources, particularly when some missionaries lived in houses that cost but $£ 2$ to erect. Walker strongly opposed such an expenditure and eventually it was conceded that the hospital should be built but 'not on the extensive scale Dr. Cook at first proposed' and at a cost of about $£ 150$ to $£ 200$. Walker went on to point out that 'we can not shut our eyes to the fact that the Baganda Christians are not very anxious to have a hospital' and indeed several fatalities following operations had actually rather prejudiced them against the idea. Nonetheless, Walker, wanting to be fair, agreed that 'still at the same time a better building than the present one is required to give a fair chance for the doctor's skill to be displayed'. 


\section{W. D. Foster}

Some expansion of the medical work there had to be for Albert Cook's elder brother Jack had, in 1898, been accepted for service in Uganda. Bishop Tucker, although a staunch friend to medicine, felt that the primary use of the medical mission was evangelical and proposed that Jack Cook, on his arrival, be sent to the primitive Batoro tribe on the western border of Uganda, a people not satisfactorily reached at that time. The Bishop and Albert Cook, in 1898, made a safari into Toro and came back strongly in favour of setting up a medical mission at Kabarole. Tucker was therefore not a little put out to learn that the Parent Committee in London had sanctioned the marriage of Dr. Jack Cook, for Toro was considered a quite unsuitable place for a newly-arrived woman at that time. Although against expansion of the medical work at Mengo the Bishop felt that his hand was forced.

Albert Cook volunteered to go to Toro in his brother's stead but, apart from the fact that he could not really be spared from Mengo, it was clear that Miss Timpson expected to go with him and that would mean having to send another woman also. The relationship between Albert Cook and Miss Timpson was causing the Archdeacon some concern; he wrote, 'I have objected to the extreme intimacy that existed between Dr. Cook and Miss Timpson and to the way in which they seemed to my mind to disregard the usual restrictions of civilized life ... I think the fear of being separated in their work in any new arrangement of the missionaries here may have hurried matters on to the crisis with Dr. Cook'. Walker was then only too pleased when Cook applied for permission to marry Miss Timpson, the more so since this would obviate the necessity of sending another woman to Toro.

Plans went ahead, for the Bishop was particularly keen on the Toro project, as indeed was Cook, although he had been but a few months at Mengo. Walker remarked that it was, of course, always more exciting to start something new than to carry on an established project and, when Cook submitted a list of items required for Toro amounting to $£ 300$, could but write, 'I am glad to think that $I$ as a parson do not require such an extensive outfit for the job $I$ have in hand'.

Meanwhile the Parent Committee, although they had originally recruited Dr. Jack Cook for work in Toro, were less keen on the project and to Tucker's annoyance, refused to sanction the funds necessary for the hospital at Kabarole. Tucker wrote to Salisbury Square that he did not need or want two doctors at Mengo and that the Toro doctor would spend most of his time itinerating and would reach 'tribes who need to be won' and that, anyway, Kabarole would only be 'a sort of medical outstation'. Walker took a more realistic point of view; firstly, he wrote with regard to Mengo 'now that we are saddled with a large hospital and extensive medical work we must carry it on properly or else give it up'. Although Walker did not approve of having two doctors at Mengo he pointed out that, now that so much medical work was undertaken, it was extremely awkward when Dr. A. R. Cook had to go away to visit a sick missionary or on safari with the Bishop. Inevitably serious cases arrived or Miss Timpson fell ill so that Miss Chadwick had to give up her school-teaching to run the dispensary. Although on the one hand they needed two doctors at Mengo, if they had them, the medical work would certainly get 'out of proportion' to the rest of the work.

In fact, the local missionaries had already gone a considerable way in founding a 


\section{Dr. Albert Cook and the C.M.S. Medical Mission to Uganda}

medical mission at Kabarole. Mr. Maddox had drawn up plans for quite an elaborate hospital consisting of two cruciform-shaped wards sixty feet in length and breadth, one for men and one for women, between which was a separate building sixteen feet square serving as an operating theatre. The operating theatre had already been built, at a cost of $£ 10$, and a further $£ 20$ expended on a dispensary. To Walker's alarm, the Bishop was now talking of getting a third doctor for Uganda. It was aggravating that although, in conversation, the Bishop could be got to agree with Walker's point of view, in the executive committee he allowed Cook's faction to have its way. He even disagreed with Walker's minutes of the meeting and made him alter them, although Walker maintained that his minutes certainly conveyed the sense of the meeting.

Salisbury Square, in addition to receiving copies of the local executive committee minutes, which were supposed to represent the missionaries' collective point of view, was also bombarded with letters containing personal opinions. The more extreme anti-medical opinions, represented by Buckley, Baskerville and the Archdeacon maintained that 'No hospitals were required for Toro nor for any place in the Nyanza mission. Send us out missionaries, if they are medical doctors so much the better, but we want missionaries'. Medical missions were 'no doubt a nice thing to have, a luxury for the native Christians ...'But, if they must have medical missions it would be far better to 'put these missions in bigoted Mohammedan towns'.

Missionaries like Maddox, Leakey and Millar, however, did favour a medical mission at Kabarole, not particularly because of its medical usefulness but because they thought it would help with the evangelical work. At the end of 1899 A. R. Cook and the Bishop paid a visit to Toro, and Maddox, the local missionary, felt that the case for a hospital was proved since Cook, who began by seeing about eighty patients a day, ended by seeing nearly four hundred and, in addition, performed several impressive operations including the miraculous restoration of sight following removal of a cataract.

The Church Missionary Society medical committee in London was not wholly against having a doctor in Toro. Dr. Lankester, their medical secretary, explained the position in a letter to A. R. Cook in July 1899. He wrote 'the rule of the medical committee is not to make any grants for a medical mission until the opening of that medical mission has been sanctioned by the committee and, therefore, as yet no grants have been made towards Toro because the Group and the Medical Committee both feel that until we have a third doctor it was not wise to open another medical mission in that part of Africa.'

It was not until 1901 that a third doctor was recruited for Uganda. Dr. Ashton Bond had graduated with the M.B. degree from Trinity College, Dublin, and, after holding house appointments in that city, obtained his M.D. degree in 1901 just before leaving for Uganda. When Dr. Bond first came to Uganda with his wife he spent over a year at Mengo as Dr. A. R. Cook was on leave in England. Meanwhile, the lay missionaries did what they could in the medical line at Toro and a Miss Allen seems to have built up quite a flourishing dispensary practice. In January 1903, the Bonds set out to march to Toro but, only a few days march from Mengo and an operating theatre, Mrs. Bond fell ill with a perforated gastric ulcer and died. Dr. Bond pushed on to Kabarole where he was made very welcome. Almost at once he 


\section{W. D. Foster}

had twelve beds set up in the old dispensary and a temporary forty-bed hospital was immediately started. One of his first patients was the King of Toro who came with a small abscess on his arm demanding the 'medicine to make him sleep'. This was given and the abscess opened, to the King's delight. Ever after he proved most useful; whenever a patient was afraid of having an anaesthetic the King came and had a word with him. During his first ten months Bond treated about one hundred inpatients, performed forty operations under chloroform and saw nearly seven thousand five hundred out-patients.

Under Bond the Kabarole Hospital flourished although he met opposition from some of his colleagues. As Bond complained to A. R. Cook, 'Blackledge views the medical work in much the same way as the Archdeacon used to view the same work at Mengo, but the latter had a much broader view of things than our friend here ...'

As well as medical work in hospitals and under the supervision of doctors nearly every Church Missionary Society mission station made some attempt to do medical work and were encouraged in this actitivity by A. R. Cook. By 1909 there were no less than seventeen dispensaries in Uganda, stretching from Mbarrara to Mbale. Some lay missionaries were particularly keen on the medical side of their work, to the alarm of the Medical Committee at Salisbury Square. Mrs. Skeens, at Iganga, without asking for permission or funds, had gradually built up in-patient accommodation of no less than thirty-five beds. Dr. R. Elliott, secretary to the Medical Committee considered that this 'surely throws too much responsibility upon unqualified ladies'. Even J. H. Cook thought she was carrying matters too far. In May 1910, Mrs. Skeens wrote to the Medical Committee enclosing plans for the building of 'a small cottage hospital' and requesting permission to raise the required money herself. She pointed out that in her present dispensary building 'the rats are so many they destroy what we have, some lovely bed jackets kept in a cupboard all riddled through with rats ...' Dr. Elliott, writing to A. R. Cook for advice, felt that they were not 'justified in putting an unqualified lady in charge of such an extensive work. She is not even a trained nurse ... B But A. R. Cook reassured him 'of course we should deprecate the ideas usually connoted by the term hospital being applied to this building. It would be more fully designated as a refuge for out-patients.' After some months' delay Mrs. Skeens was given permission to collect 'a sum not exceeding $£ 100$ ', for her purpose but the Medical Committee insisted that 'no surgical operations of a serious character should be undertaken in this rest house by non-qualified missionaries'.

As the work at Mengo hospital expanded the need for formal organization of the staff with prescribed duties and responsibilities was felt. This led to a conversation between Walker and A. R. Cook, in May 1903, and the Archdeacon's request that Cook draw up a set of rules for the running of the hospital. Here again the situation was complicated by the hospital staff also being missionaries for, in Walker's view, every missionary was under the authority of the local Executive Committee and no missionary could have any authority over another missionary unless the Executive Committee chose to delegate some of its authority. Cook agreed that 'every missionary qua missionary is under the control of the Executive Committee, yet, in a hospital, due efficiency can only be obtained by a certain amount of discipline . . . the usual hospital rules should be followed'. Cook submitted a brief set of rules for consideration 


\section{Dr. Albert Cook and the C.M.S. Medical Mission to Uganda}

by the Executive Committee in which it was proposed that all official communications should go through the 'senior medical man' as determined by the date of his joining the Church Missionary Society but that individual doctors should be quite independent as regards his own cases'. The ward sisters should be responsible to the matron. The matron could hardly be other than Mrs. A. R. Cook. At the Committee the Bishop and A. R. Cook wished that this set of rules be accepted 'as they stood' but the other seven members of the Committee, including Dr. J. H. Cook and Walker, 'proposed an alteration with regard to the clause dealing with the powers of the matron ... to make the matron, sister or sisters as far as possible independent of each other in their own sphere of work'. It was decided that guidance on this point should be sought from Salisbury Square but, in the meantime, Mrs. Cook be appointed matron, Miss Dallison sister and Miss Barton nurse 'but that the powers of the matron should be those indicated in the amendment and not those in the draft scheme'. That is the ward sister would be 'directly responsible to the doctor and not the matron'. Despite the fact that there can be no doubt that Albert Cook was a good missionary, in the evangelical sense, it is clear that his energetic efforts to forward the purely medical work for its own sake, as much as for its evangelical possibilities, created resentment among some of the other missionaries.

Great thunderstorms are a striking feature of the weather in Uganda and even today not a few fires are started by lightning. In times when grass thatch was the only available roofing for houses this hazard was much greater and many disastrous fires are recorded: the great Anglican cathedral of Namirembe was burnt down in this way in 1910. During the November rains of 1902 there were no fewer than five serious fires started in the Kampala area by lightning.

On the night of 28 November, the Mengo missionaries retired to bed just as the storm was starting about 10 p.m. Albert Cook was hardly abed when, at the height of the storm, there was 'a vivid blaze followed by a clap of thunder that shook the room'. Both the Cook brothers were out of their houses within less than three minutes but by then the hospital roof was burning furiously. Thanks to the efforts of the two hospital boys on duty, all the patients had already been carried to safety with only one casualty - a broken leg occasioned when one of the boys slipped in the mud whilst carrying a recent post-operative case.

All their patients being safe, the Cooks were able to concentrate their efforts on saving what they could of their equipment. Their order of priorities is interestingfirst the laboratory from which they managed to rescue almost everything except the high power objectives of their two microscopes. Then, turning to the operating theatre, they managed to save but a fraction of the instruments. By this time 'a perfectly uncontrollable mob of willing native helpers invaded the hospital, and much unnecessary damage was wrought by those who would fain have helped us'. All the books were salvaged although much damaged by the rain and all the hospital case-notes 'of quite inestimable value', except for the current year, were saved. More might have been saved but for the confusion; natives, thinking the beds the most valuable items, caused no little danger by dragging them out and blocking doors with them. In a matter of minutes all that could be done had been done but the hospital building was totally destroyed. The patient who had sustained a fracture of his femur was attended 
to and those patients who had not fled to their homes were accommodated for the night in the houses of the medical staff.

The following day a diligent search was made of the smouldering ashes but nothing of use was salvaged. The Commissioner of Uganda, Colonel Sadler, dispatched, early in the morning, a gang of four hundred labourers free of charge to the mission for one month to help erect a temporary hospital. The superior sort of natives also showed their concern and many chiefs made offers of help. The Katikiro's comment showed how his aspirations had risen and his views widened by his recent visit to England. He said: 'If God has allowed our hospital to perish, it is to show us that we must build a bigger and better one'. With such sentiments the Cooks were quite in agreement and forthwith set about the task and the 'bigger and better' hospital which arose within two years from the ashes still stands on Namirembe Hill today. The Cooks immediate estimate of the damage in money terms were that about $£ 200$ worth of instruments and bedding had been lost but that the total damage could not be far short of $£ 1,000$.

Those patients who could not be sent home were housed in a school building which the native church made available and this was the hospital until Colonel Sadler's labourers had knocked up a temporary hospital. This building, which was to do duty as an isolation ward even after the new hospital was built, consisted of two twelvebedded wards with an operating room between them, an obstetric ward and, of course, a 'pathological room'.

Meanwhile the Cooks lost no time in making plans for the rebuilding of the hospital, naturally on a much grander scale than that which had been destroyed. Early in 1903 Dr. Lankester, the Secretary to the Church Missionary Society medical committee, was shocked to hear that the Cooks estimated that the new hospital would cost 'nearly $£ 2,000$ ' - he had further shocks to come! A special appeal fund was opened and the immediate response was very gratifying; by the beginning of February $£ 652$ had been subscribed and a great deal of new interest in the Uganda mission had been aroused. This appeal eventually raised well over $£ 1,000$. Because of the fire risk the Cooks were determined that their new hospital should be built with a cement floor, brick walls and a corrugated iron roof; this last would cost nearly $£ 700$ alone. It is, therefore, not surprising that the local executive committee should, by the September when most of the estimates were available, minute a request for the sum of $£ 2,400$ in addition to the help already promised, in kind, by the local chiefs and estimated to be worth about $£ 175$. This sum was quite beyond the resources of the Church Missionary Society medical committee and the secretary wrote to the Cooks insisting that some economies be made. Moreover, the committee was not a little annoyed by the Cooks' flagrant disregard of the regulation governing new mission buildings. It was clearly laid down that detailed plans, specifications and estimates should be submitted before any grants could be expected, yet the committee had received nothing but the demand for $£ 2,400$. As Dr. Elliott complained, no definite application for a building grant had been made until the demand of September was received and by that time a building was already in the course of erection. Elliott felt bound to say that although the Committee was "very unwilling to bind you with red tape; they feel, however, strongly that their rules should have been complied with and their 


\section{Dr. Albert Cook and the C.M.S. Medical Mission to Uganda}

actual consent gained before such a large expenditure was embarked on.' In fact some plans were received in London before this rebuke was sent off but the postmark showed that they had only left Kampala on 6 November. Even Bishop Tucker was forced to admit that the medical committee had good grounds to complain.

Albert Cook was also pressing for a new post-mortem room and although the medical committee in a manner which must, in the circumstances, be regarded as most liberal, had agreed to this rather un-missionary expenditure they asked that the building be deferred as, at that time, they were without the necessary funds. Albert Cook suggested that he might be allowed to spend the accrued income of his then non-existent endowed beds but this the committee would not permit. His missing high-power microscope objectives were however replaced with a gift from his mother.

All problems were gradually overcome and the new hospital, the foundations of which had been begun in July 1903 was ready for opening on 28 November 1904, exactly the second anniversary of the fire. The opening was something of an occasion in the young Protectorate and as many as possible of the European community and native notables attended including the little Kabaka, Daudi Chwa. The guests toured the most impressive new hospital which Albert Cook described for the readers of the Church Missionary Society magazine, Mercy and Truth: 'The building is just over 200 feet long, with five transverse wings sixty feet wide. It may be roughly described as being like a double cross, with an operating block and hall in the centre and a large block at each end. The centre tower is two-storeyed, the upper storey being fitted up as a laboratory for pathological work. Altogether there are seventeen rooms. The general men's ward is seventy feet long by twenty feet wide, having two wings of 400 square feet each, running off east and west from its centre. The general women's ward is similar, but the east wing is cut off by a wall to form an obstetric ward.' There was also a fine, well-equipped operating theatre.

Whilst the main hospital was in course of erection Albert Cook was also thinking about rebuilding the dispensary or out-patient department. It would have been useless to expect that the Church Missionary Society should finance such work, but Cook thought that Mr. Henry Wellcome of Burroughs Wellcome Ltd. might be persuaded to foot the bill. By October 1904 this had been arranged and Mr. Wellcome had agreed to pay the whole cost of a new dispensary at a cost of $£ 364$ and to supply free of charge a six months' supply of his own firm's 'Tabloid' drugs, worth $£ 120$, provided that, during the period, no other firms' drugs were used; future orders for drugs being 'left to the good feeling of the society'. The 'Wellcome' dispensary was opened in October 1905 and was said to be 'the best building in Uganda for its size'. A local gift of bricks had allowed a saving of $£ 24$ to be made on the cost of the building and this Cook used to build the new post-mortem room which he had wanted for the new hospital but which the Church Missionary Society had not been able to afford. The handsome building had a cement floor made of a mixture of sand, swamp clay, chopped grass and cow dung which set as hard as Portland cement so that it could even be washed down and the roof was of corrugated iron. There was a large sheltered porch in which the patients were separated by sexes and divided into old and new cases. The porch led by passages to two doctors' consulting rooms which were equipped with couch, screen, washstand, table and all necessary instruments. Having 


\section{W. D. Foster}

seen the doctor, the patients passed into a large hall where benches were provided 'for chiefs and Indians', and waited their turn to go to the actual dispensary to collect their medicines or to a separate little room where dressings could be changed or minor operations performed. In September 1909 Albert Cook wrote to Mr. Henry Wellcome again saying that he was contemplating building a new storehouse for the dispensary as they had at this time over a thousand drugs available and the old store was most inconveniently sited so that much time was wasted by dispensers going to and fro. It was estimated that the cost of a suitable building would be about $£ 100$ but Cook felt that Mr. Wellcome would 'wish everything connected with the Wellcome dispensary to be built by yourself'. He appears to have judged correctly, for the following year Mr. Wellcome gave another $£ 150$.

By 1908 the medical work at Mengo which had grown steadily for the first ten years appeared to have settled down, there having been no significant growth during the last two years. The hospital was now dealing with about 1,500 in-patients and over 80,000 out-patients a year which was as much as two doctors could cope with properly. But if the work could not be increased in quantity it could be improved in quality and during the next two years the Cooks were not idle in this respect. First there was the isolation block which had originally been erected as a purely temporary structure to house the patients immediately after the disastrous fire of 1902 and, like so many temporary buildings of this world, had had its life prolonged far beyond original intentions. This building was now tottering to its fall and early in 1908 Albert Cook, this time sticking to the Church Missionary Society rules, submitted plans for a new isolation hospital. The original estimated cost was nearly $£ 1,000$ but the Cooks eventually undertook to build it, without the services of a contractor, at a cost of £831. Half this sum was received as a donation from Sir William Willcocks and the work was put in hand in December 1908. The block, which took a year to build, consisted of two large and three small wards as well as hall, operating room, store and nurses' quarters. It accommodated forty-three beds and thus brought the total beds for the hospital up to 130. Mr. Theodore Roosevelt, the ex-president of the United States, who happened to be on a shooting trip to Uganda was persuaded to open the new block, which he did on 12 December 1909. The early history of the Roosevelt Block, as it was called, was unfortunate. Whether or not the Cooks' attempts at economy during its construction were to blame is difficult to estimate but, possibly, doing without the services of a professional contractor was a false economy. At any rate, during a storm in October 1910, just ten days after the cathedral at Namirembe had been destroyed by lightning, the roof of the Roosevelt block was blown off.

Although the medical work at Mengo Hospital had, by 1908, reached such proportions that it was as much as the Cook brothers and their team of five European nurses could manage efficiently, improvement and expansion was never far out of mind. In early 1909 a nephew of the Cook brothers, Dr. E. N. Cook, joined his uncles at Mengo bringing with him X-ray equipment, the cost of which the family had raised privately. Mengo Hospital had from its foundation always made a certain amount of money in fees from patients who could afford to pay, whether native, Asian or European. The scale of charges was as follows:-Ordinary hospital out- 


\section{Dr. Albert Cook and the C.M.S. Medical Mission to Uganda}

patient fees 1-5 cents (a cent was the sixth part of a penny), but for patients in European coats 10 cents; Chiefs and Indians were charged 1 rupee for a visit and a four-day supply of medicine; Goanese and Europeans-3 rupees for a hospital consultation and 5 rupees for a home visit; and operation fees from 5 to 300 rupees. In-patient charges were 5 rupees per diem, including board. Africans were not charged fees as in-patients, except an operation fee for circumcision in venereal cases. In 1898, the first full year of activity, local receipts amounted to only 908 rupees (about £34) but this income had grown steadily so that in 1910 it had reached 17,863 rupees (about $\mathrm{f670}$ ) and these funds, with the approval of the local committee, could be used to improve the hospital. Much of the money was derived from the relatively well-off Europeans and Asian traders, Mengo Hospital being the only place in the whole of Uganda where they could obtain skilled treatment; the little government hospital at Entebbe served only local needs. Charges were usually modest, for example, 15 rupees for a confinement but, when the new salvarsan treatment for syphilis became available, cables such as the following were sometimes received: 'Have Indian patient rapidly advancing syphilis wants salvarsan, expense immaterial, respected rich merchant, will be paying in-patient, reserve dose for him and receive early date'. It is not surprising that, in these circumstances, fees recovered from three patients could be made to pay for as many as thirty-three courses of treatment.

Private patients came from all over East Africa, usually for operations and were usually 'stricken in soul as well as in body' and 'almost without exception they welcome spiritual work amongst them and most of them badly need it'. Writing home in 1910, Albert Cook said that they had recently treated English, Scots, Irish, French, German, Austrian, Italian, Greek and Syrian patients, 'not counting Asiatics'.

Albert Cook first raised the possibility of building a special ward or small hospital for Europeans in a letter to Salisbury Square in July 1909. He wrote 'At present our European patients who are steadily increasing in number and who add very largely to the income of the hospital have to be housed in two small private wards containing one bed apiece. If more than two are in at any one time they have to be put in a screened off part of the general ward-we have had four in at one time. Our proposal is to build a small European hospital of five or six beds in private rooms so as to form a third side of the hospital quadrangle. The cost will roughly be $£ 700$ '. He further pointed out that his proposed European hospital 'would be (with the exception of a small government hospital at Entebbe) the only hospital for Europeans within the vast area of the Uganda Protectorate. The Entebbe hospital is for purely local needs, ours would be (or perhaps I should say is) for whether we get the hospital or not we shall assuredly have to treat the patients, for the whole Protectorate and beyond too, for we have had several cases from the East African Protectorate and even from German East Africa. The Entebbe hospital gives no religious teaching, it is a government hospital pure and simple. The first object in ours would be to influence the patients spiritually'. The Medical Committee in London replied giving general approval to the building on which missionaries should have first claim but considered that 'the cost should be considerably less than $£ 700$ and should be met out of local fees'. Under these conditions nothing could be done immediately but the following year an unexpected, but doubtless not unearned, 'windfall' made the scheme 


\section{W. D. Foster}

for a European hospital possible. A Mr. and Mrs. Walker of Leicester with their daughter visited Mengo Hospital as part of a holiday tour of Africa. They were 'well known for their keen interest in Church Missionary Society work' and spent a fortnight at Mengo. On the return journey Mrs. Walker died and was buried at sea and the family wrote to Albert Cook asking if there was any project at Mengo which they could finance as a memorial to Mrs. Walker. Cook 'took this as an indication of God's will that the time had come for the erection of the English hospital' and obtained a promise of $£ 800$ for this purpose from the Walker family. He at once, as on a previous occasion, without submitting plans and estimates to Salisbury Square, 'set about the preliminary steps' and built a large brick shed and began laying in bricks.

Other improvements to Mengo Hospital completed about this time were the installation of electric light and an internal telephone system. Dr. Ernest Cook seems to have taken this matter in hand and understood the technicalities. The electrical system was required not only for lighting but for the $\mathrm{X}$-ray equipment, surgical cauteries and other surgical equipment. In 1909 with the agreement of Archdeacon Walker the 'Pathological Room' was enlarged at a cost of $£ 60$ and new equipment such as proper laboratory sinks, burettes, filter pump etc. added. It seems that even some bacteriological culture work was undertaken for we know that Mengo laboratory possessed an incubator, that Sir David Bruce supplied cultures of Salmonella typhi and Brucella melitensis and special labels for bacteriological work were ordered. From the first the Cooks began to build up a good medical library at Mengo. Their mother supplied them regularly with the British Medical Journal, a friend sent on his copies of the Lancet, and as soon at the Journal of Tropical Medicine began publication in 1898 the Cooks subscribed and contributed to it. Textbooks and monographs were collected and old editions replaced by new.

The Cook brothers were regarded as the consultants of East Africa and patients were referred to them by both government medical officers and private practitioners. Their well-equipped ophthalmic department was particularly useful in serving to 'awaken fresh interest in the mission work' as well as a source of revenue. Successive Governors of Uganda supported Mengo Hospital with personal contributions and availed themselves of the Cook's medical opinion in health matters. In 1907 it was suggested that the young Kabaka of Buganda might visit England and Jack Cook received a letter saying that 'His Excellency is uncertain whether this would be wise in view of the fact that the Kabaka is not a strong lad, and there is the possibility of his suffering from change of climate, His Excellency would be much obliged if you would favour him with an opinion on this point'. J. C. R. Sturrock, the official acting as the Kabaka's tutor, wrote to Cook 'Daudi has suddenly got a little seedy . . . . He indignantly denies that he ate a lot of cakes yesterday!! But I have a notion the symptoms point to something of the sort. Can you prescribe?' In fact the little Kabaka was suffering from a sore throat and painful cervical glands and despite his tutor's opinion we may accept the former's indignant denials. On yet another occasion, during a measles outbreak, Albert Cook recommended the fumigation of Daudi's room with sulphur and formalin and the re-whitewashing of his house.

Even in the first decade of the present century Uganda was becoming a place which the more adventurous were visiting on holiday and the Cooks were asked advice on 


\section{Dr. Albert Cook and the C.M.S. Medical Mission to Uganda}

health precautions and their hospitality claimed. The visit of the Walker family which turned out so profitably for the mission has been noted and there were other visitors. The most famous visitor was Winston Churchill. A letter from Salisbury Square alerted the Cooks to this visit; 'The importance of interesting him in the mission is of course apparent. I am sure you will do what you can to show him what a medical mission is', wrote Dr. Harford. The Cooks evidently did their best for Churchill later wrote, in his book My African Journey, that he found the Church Missionary Society hospital 'a model of what a tropical hospital for natives ought to be'.

The Church Missionary Society Hospital at Kabarole in Toro had been opened in 1903 with Dr. Ashton Bond in charge. The medical need in Toro was, if anything, greater than in Buganda. The inhabitants were at a distinctly lower cultural level and disease of every kind rife. Dr. Bond had built up the hospital from a small dispensary and by 1906 had thirty-eight beds through which passed 576 in-patients during the year and, in addition, he saw nearly 25,000 out-patients and performed 105 surgical operations. Kabarole certainly was not the medical out-station originally envisaged by Bishop Tucker and, in fact, Dr. Bond only spent fifty-two days in the year away from his base visiting outlying villages. By 1908 Dr. Bond had increased the size of his hospital to fifty beds and was actively planning to rebuild it on a larger scale. Money had been raised and the main difficulty seemed to be to get a competent building contractor so far from the capital. In February 1909, Bond, who still had not got his new hospital, wrote to Bishop Tucker pleading his cause and saying that, including makeshift arrangements he now had beds for seventy-five in-patients. For a single-handed doctor, Bond was doing a great deal of work including almost half as many major surgical operations as were done at Mengo which could muster a very competent operating team. But in 1909 the building of the new hospital began.

From the first the Church Missionary Society medical mission had appreciated the desirability and even necessity of training natives in medical work but their first task had been to overcome the marked native prejudice against such work. As Cook paraphrased it, their attitude was 'I do not want to help you to look after the sick, it is nasty work and might be dangerous'. At first native assistants could only be recruited from among the grateful patients whom the Cooks had treated. But, by 1899, there were six 'dispensary boys' at Mengo and Albert Cook was full of praise for them; 'these dear lads . . . lead a most self-denying life, with hard work and no wages, but just the clothes and food they need ...' It seems, however, that it was their humble, unostentatious, Christian way of life that was their chief merit. Dr. Bond was no less enthusiastic in training natives and had ten boys between the ages of twelve and eighteen training as hospital assistants. One or two of these were "fairly smart and appear to take an interest in the work, but they all require constant supervision in everything they do and a wonderful amount of patience, as they need to be told the same thing over and over again, and generally, when possible, they manage to do the wrong thing ... A Albert Cook confessed also that the work of 'training the native assistants has been long and arduous, and after ten years we can only point to four thoroughly trustworthy male native assistants, though we also have another half dozen in the process of training'. The training of female nurses was even more 


\section{W. D. Foster}

disheartening, for it took two or three years to make even a moderately useful nurse of them and, owing to the early age of marriage and the disgrace to a girl to be unmarried in Uganda, they were usually lost just as they were becoming useful. Even so, despite their deficiencies, the hospital work would have been impossible without the native assistants. In 1909, Albert Cook wrote to Henry Wellcome that he hoped 'the time is not too far distant when we can begin to train in earnest the more promising Baganda students for a medical certificate or diploma. Of course, it will be many years yet ere this consumation be reached but the preliminary steps have already been taken and doubtless a medical faculty will be established in the future Mengo University'. In the same year Drs. A. R. Cook, J. H. Cook and E. N. Cook, held a 'medical sub-conference' at Mengo and addressed their minds to a number of questions of policy in the medical work. One of the questions considered was to what extent it seemed desirable to 'carry on any system of medical training of natives apart from that needed for the workers in each individual mission'. In their answer they said that 'it is obvious that eventually in the future university a medical faculty will have to be established and the hospital affords plenty of clinical material for such training. But the scheme bristles with difficulties ...'A Apart from the problem of physical facilities, classrooms, dissecting room etc. "on the native side, a medical education is not popular, nor do they readily see the advantage of paying for a medical education so long as well paid posts in government service are open to them'. Again, the following year, in a letter to Salisbury Square, Albert Cook wrote 'Central Africa needs a university for the natives, and its seat will be at Mengo . . . In this a medical training college should take its appropriate part . . . it has got to come and by God's blessing it will come. If we do not live to see it our successors will'.

The difficulties were, of course, enormous and to obtain students with the appropriate social attitudes and sufficient general education to make even the most elementary medical training meaningful proved, at the time we are considering, to be impossible. At another 'medical sub-conference' held in April 1911, it was agreed that experience so far showed that the time had not yet come for training native assistants. Nonetheless, the idea of training Africans in medicine was not lost sight of. In 1917 Mengo medical school opened with seventeen students in the first class. The course was planned to last for three years and the government annual report to the Colonial Office for 1918-1919 reported that the school was 'well established' and 'fulfilling a valuable function in qualifying native dressers and dispensers'. But Cook later admitted that the Mengo medical school was 'chiefly interesting because it foreshadowed the much larger and more complete scheme of medical training, which the government with their infinitely larger resources in men and money initiated under Major Keane and Dr. Owen at Mulago in 1924'.

Of perhaps greater importance than the Mengo medical school was the foundation of a school for the training of midwives in obstetrics and the care of infants. In 1918, as half a century later, stillbirths and infant mortality formed a most profitable field of medical endeavour. About 1918 Albert Cook estimated that the maternal mortality rate was about four per cent, or some ten times that in England, and that only about forty-five out out of a hundred conceptions were safely delivered and survived to the end of the first year. 


\section{Dr. Albert Cook and the C.M.S. Medical Mission to Uganda}

Mrs. Albert Cook resolved to take the matter in hand and, about 1918, began to train native girls in midwifery following a curriculum based on that of the Central Midwives Board. Meanwhile the wife of the Governor, Sir Robert Coryndon, was interested in the project, and Lady Coryndon raised $£ 4,000$, to which the government added a further $£ 1,000$, for the building of a proper midwives' training school. This Sir Robert and Lady Coryndon opened in June 1921. However, the social attitudes of the student-midwives presented problems that might well have daunted less ardent teachers. The fact was, as Albert Cook put it, 'the moral dangers for these attractive young women were very grave'. Mrs. Cook found it necessary to censor both incoming and outgoing correspondence having discovered that some letters received by the girls contained 'direct incitement to immorality'. Cook reported that of 112 students who actually passed the Uganda midwives' examination twenty-four had to be dismissed for immorality and a further eleven for laziness. Twenty-five more left to get married but fifty trained midwives were still at work. These were sent to stations all over Uganda and ran ante-natal and child welfare clinics by themselves with excellent results, so that maternal mortality, at these midwife-run centres, was reduced to almost one-tenth of the general level.

\section{ACKNOWLEDGEMENTS}

I am most grateful to the Librarian of the Albert Cook Library for access to the Mengo manuscripts and clinical notes and to the Church Missionary Society in London for access to their archives. I should also like to thank Miss Ann Ord for typing this paper.

\section{REFERENCES}

The chief sources upon which this article is based are the Mengo manuscripts now housed in the Albert Cook Library at Makerere University College, Kampala and the archives of the Church Missionary Society in London. The Mengo manuscripts consist of boxes of papers of all sorts; letters received, copies of letters sent, bills, plans, estimates, etc. They are not indexed in any way. The relevent manuscript material in the Church Missionary Society archives is indexed in their Summary Books for the Eastern Equatorial African Mission 1892-1897 and for the Uganda Mission 1898-1905. Another most important manuscript source is the Mengo notes also preserved in the Albert Cook Library which consist of the clinical notes of most of the in-patients seen at Mengo hospital from its foundation in 1897.

Reference has also been made to two printed sources: Doctor Albert Cook's autobiography Uganda Memories, Kampala, 1945, and the many articles contributed between 1897 and 1910 by both A. R. Cook and J. H. Cook to the Church Missionary Society magazine Mercy and Truth. 